\title{
Macroporous hydroxyapatite scaffolds for bone tissue engineering applications: Physicochemical characterization and assessment of rat bone marrow stromal cell viability
}

\author{
Joaquim M. Oliveira, ${ }^{1,2,3}$ Simone S. Silva, ${ }^{1,2}$ Patricia B. Malafaya, ${ }^{1,2}$ Marcia T. Rodrigues, ${ }^{1,2}$ \\ Noriko Kotobuki, ${ }^{3}$ Motohiro Hirose, ${ }^{3}$ Manuela E. Gomes, ${ }^{1,2}$ Joao F. Mano, ${ }^{1,2}$ \\ Hajime Ohgushi, ${ }^{3}$ Rui L. Reis ${ }^{1,2}$ \\ ${ }^{1}$ Department of Polymer Engineering, 3B's Research Group - Biomaterials, Biodegradables, and Biomimetics, \\ University of Minho, Campus de Gualtar, Braga 4710-057, Portugal \\ ${ }^{2}$ PT Government Associated Laboratory, IBB - Institute for Biotechnology and Bioengineering, Braga, Portugal \\ ${ }^{3}$ Research Institute for Cell Engineering (RICE), National Institute of Advanced Industrial Science and Technology \\ (AIST), Nakoji 3-11-46, Amagasaki, Hyogo 661-0974, Japan
}

Received 14 November 2007; revised 26 March 2008; accepted 16 July 2008

Published online 8 September 2008 in Wiley InterScience (www.interscience.wiley.com). DOI: 10.1002/jbm.a.32213

\begin{abstract}
In this work, a new methodology is reported for developing hydroxyapatite (HA) scaffolds using an organic sacrifice template. The novelty of work consists of possibility of obtaining porous and highly interconnected scaffolds mimicking the sacrificial component. Our purpose consisted of evaluating the physicochemical properties of the HA scaffolds by means of Fourier transform infra-red spectroscopy, X-ray diffraction analysis, and scanning electron microscopy (SEM) attached with an Xray detector. The HA scaffolds obtained possess a porosity of $\sim 70 \%$, and macropores diameter in the range of 50-600 $\mu \mathrm{m}$. In contrast, results regarding the microcomputed tomography analysis have demonstrated both high pore uniformity and interconnectivity across the scaffolds. The compressive strength of the HA scaffolds was found to be $30.2 \pm 6.0 \mathrm{MPa}$. Bioactivity of the HA scaffolds was assessed by immersion into a simulated body fluid solution, in vitro. SEM observations have showed a deposition of apatite on the surface of the HA scaffolds, with a "cauliflower-like" morphology after 1 day, and tend to be more pronounced with the immersion time. The changes
\end{abstract}

in calcium and phosphorus concentration were monitored by inductively-coupled plasma optical emission spectrometry. Cytotoxicity of the HA scaffolds was preliminarily investigated by carrying direct observation of mouse fibroblasts cells (L929 cell-line) death in the inverted microscope, and then cell viability was determined by means of carrying out a MTS assay. Complementarily, a luminescent cell viability assay based on the quantification of adenosine triphosphate was performed using rat bone marrow stromal cells (RBMSCs). A LIVE/DEAD assay and SEM analysis allowed the visualization of the RBMSCs adhesion and proliferation on the surface of the HA scaffolds. According to the results obtained from 3D architecture, mechanical properties, biocompatibility, and adhesion tests, it is suggested that HA scaffolds has potential to find applications in bone tissue engineering scaffolding. (C) 2008 Wiley Periodicals, Inc. J Biomed Mater Res 91A: 175-186, 2009

Key words: hydroxyapatite; bone tissue engineering; rat bone marrow stromal; cells; scaffold; cell viability
Additional Supporting Information may be found in the online version of this article.

Correspondence to: J. M. Oliveira; e-mail: miguel.oliveira@ dep.uminho.pt

Contract grant sponsor: Portuguese Foundation for Science and Technology (FCT); contract grant number: SFRH/BD/21786/2005

Contract grant sponsor: POCTI, FEDER programmes

Contract grant sponsor: STREP Project HIPPOCRATES; contract grant number: NMP3-CT-2003-505758

Contract grant sponsor: European NoE EXPERTISSUES; contract grant number: NMP3-CT-2004-500283

(C) 2008 Wiley Periodicals, Inc.

\section{INTRODUCTION}

Bone lesions above a critical-sized segmental defect remain a huge challenge to reconstructive surgery and regenerative medicine. This is mainly due to the fact that bone has a limited ability to heal. ${ }^{1,2}$ In many clinical situations there is the need for a surgical intervention and the use of autografts, ${ }^{3,4}$ allografts, or xenografts ${ }^{4,5}$ transplantation. Still, the preferred clinical strategy is the autologous transplantation, because it avoids the problem of immune rejection $^{6}$ and the consequent administration of drugs for immunosupression of the host. ${ }^{7}$ Bone auto- 
grafts consists of bone portions either cancellous or cortical, ${ }^{4}$ harvested from other skeletal locations, which are then transferred into the defect area that is aimed to repair. ${ }^{8}$ Although, the limited bone graft volume available, consequent donor site morbidity ${ }^{5,9}$ and postoperative pain ${ }^{10}$ are seen as the major constraint in using autografts. Therefore, we can say that the currently available treatment possibilities are far from being a truly ideal solution. To circumvent these limitations great efforts are focused on developing implantable materials either synthetic or natural-based to be used as implants. ${ }^{11-13}$ For instances, synthetic materials based on hydroxyapatite (HA), $\mathrm{Ca}_{10}\left(\mathrm{PO}_{4}\right)_{6}(\mathrm{OH})_{2}$, have demonstrated a great potential for being used as bone substitutes ${ }^{13-15}$ or fracture repair devices. ${ }^{16}$ The great interest in using HA or other ceramic materials arises from the possibility to improve the clinical outcome because of their osteoconductive behavior. ${ }^{14,17}$ However, these biomaterials alone are not always as effective as bone autografts, because they lack the osteogenic and osteoinductive properties. ${ }^{18,19}$

More recently, it has been reported that by applying the tissue engineering (TE) principles, ${ }^{10}$ that is by seeding bone marrow stem cells into scaffolds, the so-called constructs ${ }^{20}$ or prostheses, ${ }^{21}$ it was possible to recreate an regenerative environment at the defect area, which resulted in a more favorable healing. Despite the important advances, a wide range of problems related with the tissue-engineering approaches remains unsolved. For example, many bone tissue engineering constructs developed showed that bone formation in vitro, only occurred at the surface. ${ }^{22}$ Therefore, it seems that much has to be done and improvements of the cell culture techniques $^{23}$ and appropriate scaffolds architecture are needed for developing successful constructs that can be used in the clinical practice. Therefore, there is the need for continuously improving the development of processing routes towards the fabrication of biocompatible with adequate 3D porous structures and mechanical properties.

In this work, we report a methodology for developing HA scaffolds with a controllable architecture to find applications in tissue engineering of bone scaffolding. The physicochemical characterization of the macroporous HA scaffolds was performed by using Fourier transform infra-red (FTIR) spectroscopy, X-ray diffraction (XRD) analysis, and scanning electron microscopy attached with an X-ray detector (SEM/EDS). The microstructure of the HA scaffolds was examined using microcomputed tomography $(\mu-\mathrm{CT})$ analysis. The mechanical properties of the HA scaffolds were assessed under compression testing.

The bioactive behavior of the HA scaffolds was assessed by immersion into a simulated body fluid (SBF) solution. The changes in calcium and phos- phate concentration in the SBF solution were monitored by inductively-coupled plasma optical emission (ICP-OES) spectrometry.

Cytotoxicity of the HA scaffolds leachables was evaluated by carrying out a cellular viability assay (MTS test) on mouse lung fibroblasts cells, which were previously in contact with the different HA extract fluids. Rat bone marrow stromal cells adhesion and morphology were also analyzed by SEM and under a 3D fluorescence microscope, whereas the cell viability and proliferation were assessed by carrying out the Luminescent and LIVE/DEAD cell viability assays.

\section{MATERIALS AND METHODS}

\section{Preparation of HA scaffolds}

Calcium hydroxide (Riedel-de Haën, Germany) and ortho-phosphoric acid 85\% (Panreac, Spain) solution were used to prepare separately, two precursors (Ca and P) solutions. HA powders were obtained by adding in a controlled manner, appropriate amounts $(\mathrm{Ca} / \mathrm{P}$ molar ratio of 1.67 was always used) of these solutions, using a peristaltic pump (Gilson Miniplus 3, France) at a speed rate $17 \mathrm{~mL}$ $\min ^{-1}$. The precipitation of the HA particles occurred by adjusting the $\mathrm{pH}$ of the media to 11 with a $33 \%$ ammonium hydroxide (Riedel-de Haën, Germany) solution. Then, precipitate was filtered under vacuum and the excess of water removed by drying the filtrate at $60^{\circ} \mathrm{C}$ for $24 \mathrm{~h}$. After milling the HA pellets until obtain a fine powder, the HA scaffolds were fabricated. The procedure for obtaining the HA scaffolds is summarized in Figure 1. Firstly, a HA slurry was prepared by dispersing HA powders in methanol for $48 \mathrm{~h}$ (step 1). Then, polyurethane (PU, Eurospuma SA, Portugal) cylindrical sponges $(10 \times$ $8 \mathrm{~mm}^{2}$ ) featuring fully interconnected pores were dipped into the slurry until total impregnation. To prevent the formation of an external skin-like layer, the impregnated PU sponges were transferred to a centrifuge and the excess of slurry was removed by centrifuging at $60 \mathrm{rpm}$ for $1 \mathrm{~min}$ (step 2), followed by drying at $37^{\circ} \mathrm{C}$, for $24 \mathrm{~h}$ (step 3) to avoid the formation of cracks. Finally, the impregnated sponges were placed inside the furnace and the PU matrices burned at $900^{\circ} \mathrm{C}$ for $24 \mathrm{~h}$, followed by sintering the HA scaffolds at $1300^{\circ} \mathrm{C}$ for $3 \mathrm{~h}$ (step 4). The HA scaffolds were allowed to naturally cool inside the furnace (step 5) and finally sterilized by ethylene oxide gas. Figure 2 shows the typical HA scaffolds obtained, where replica of the PU sponge pores can be observed.

\section{Characterization of the HA scaffolds}

Fourier-transform infra-red spectroscopy

Potassium bromide (KBr, Riedel-de Haën, Germany) was used to prepare transparent discs [1:10 of sample/KBr 


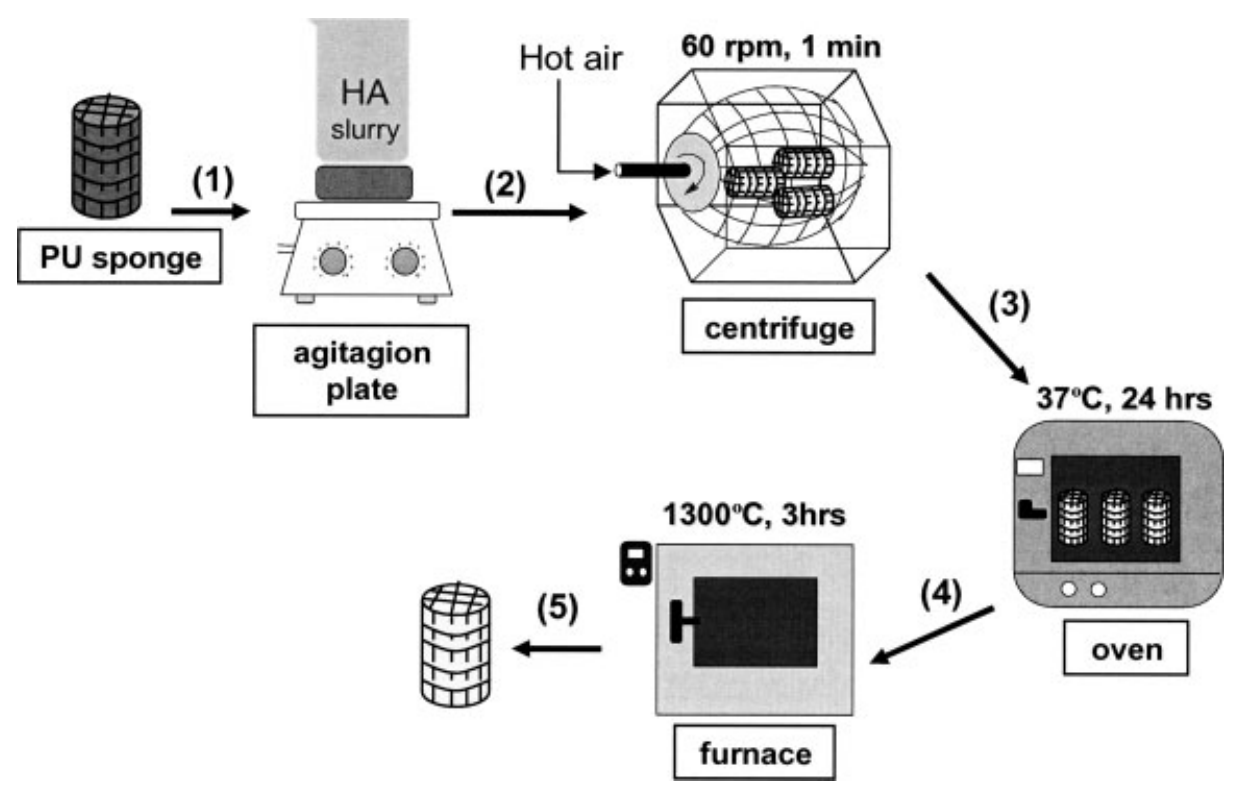

Figure 1. Schematic representation of the production route of the HA scaffolds.

(wt/wt)] for Fourier transform infra-red (FTIR) analysis. A Perkin-Elmer 1600 series spectrophotometer (Perkin-Elmer, UK) was used to record the spectra that were collected with a minimum of 32 scans and resolution of $2 \mathrm{~cm}^{-1}$. The chemical changes of HA after sintering was examined over a region of $4400-450 \mathrm{~cm}^{-1}$.

\section{Thermogravimetric analyses}

Thermal stability and composition of the PU sponges, PU sponge impregnated with HA before burning, and HA scaffolds sintered at $1300^{\circ} \mathrm{C}$ was assessed by thermogravimetric (TGA) analysis. A TA-Q500 analyser (TA Instruments, USA) was used. The data were obtained using a ramp rate of $5^{\circ} \mathrm{C} \mathrm{min}^{-1}$.

\section{X-ray diffraction measurements}

Crystallinity and phase content of HA powder, sintered HA and HA scaffolds were investigated with X-ray diffraction (XRD) analysis, using an X-ray diffractometer (Philips PW 1710, The Netherlands). XRD patterns were examined in the region of $2-65^{\circ}$ with a step size $0.02^{\circ}$ for $2 \theta$ and scan speed of $0.6^{\circ}$ per min.

\section{Scanning electron microscopy}

A scanning electron microscope attached with an energy dispersive electron probe X-ray analyzer (SEM-EDS, Leica Cambridge S-360, UK) was used to analyze both microstructure of HA scaffolds before and after immersion into a simulated body fluid (SBF) solution, and PU sponges. All specimens were coated with gold using a Polaron SC 502 (Fisons Instruments, UK) coater, prior to observation.

\section{Micro-computed tomography}

The 3D structural and architectural information of the HA scaffolds was assessed quantitatively and qualitatively, by means of microcomputed tomography ( $\mu-\mathrm{CT}$ ) analysis and using a Scanco 20 equipment (Scanco Medicals, Switzerland). A series of about $9002 \mathrm{D}$ slices with a scanning resolution of $11 \mu \mathrm{m}$ were obtained by irradiating the specimen with penetrative X-rays of $50 \mathrm{keV}$. Mimics ${ }^{\circledR}$ from Materialise (Belgium) was used as image processing software. The porosity along the HA scaffolds was also eval-

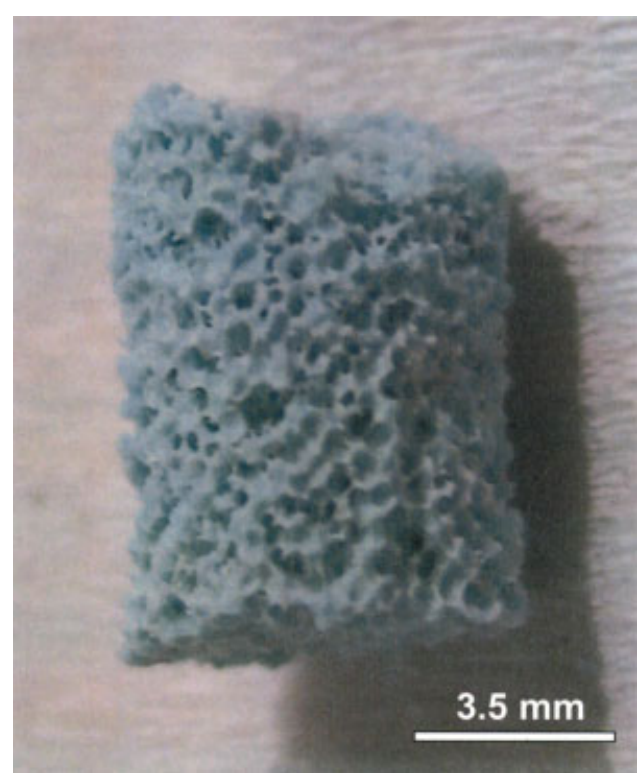

Figure 2. Macroscopic appearance of the HA scaffolds after sintering at $1300^{\circ} \mathrm{C}$. [Color figure can be viewed in the online issue, which is available at www.interscience.wiley.com.] 
uated by 2D histomorphometric analysis using a threshold 300 (Th 300).

\section{Mechanical testing}

Compression tests (dry state) were performed using a Universal Testing Machine (Instron 4505) containing a load cell of $50 \mathrm{kN}$. Experiments were conducted using a minimum number of 10 scaffolds.

\section{Bioactivity test}

HA scaffolds were immersed in a simulated body fluid (SBF) solution at $(37 \pm 1)^{\circ} \mathrm{C}$ to assess the bioactivity in vitro. ${ }^{24}$ After each immersion time (1,3, 7, and 15 days), the scaffolds were immediately rinsed with distilled water, dried at room temperature for $24 \mathrm{~h}$ and then dried in the oven at $60^{\circ} \mathrm{C}$ until constant weight. The concentration of the $\mathrm{Ca}$ and $\mathrm{P}$ ions in the SBF solution was also measured by inductively-coupled plasma optical emission (ICP-OES, JY 70 plus, JobinYvon, France) spectrometry. Triplicate samples were analyzed for each immersion time and averaged results calculated.

\section{In vitro cell culture studies}

\section{Cytotoxicity screening}

The MTS viability test was performed to investigate the cytotoxicity of the HA scaffolds leachables. A cell line of mouse lung fibroblasts (L929 cells) purchased from European Collection of Cell Cultures (ECACC, UK). This type of cells has been used in cytotoxicity assays to preliminarily test biocompatibility of potential biomaterials. ${ }^{25}$ L929 cells were cultured in an DMEM (Dulbecco's-Modified Eagle's Medium, Sigma, Germany) medium supplemented with $10 \%$ fetal bovine serum (FBS, Gibco, UK), 1\% antibiotic-antimycotic (Gibco, UK) solution containing 10,000 units $\mathrm{mL}^{-1}$ penicillin $\mathrm{G}$ sodium, $10,000 \mu \mathrm{g} \mathrm{mL} \mathrm{m}^{-1}$ streptomycin sulphate and $25 \mu \mathrm{g} \mathrm{mL}^{-1}$ amphotericin B as Fungizone ${ }^{\circledR}$ in $0.85 \%$ saline. The $\mathrm{L} 929$ cells were incubated in an atmosphere containing $5 \%$ of $\mathrm{CO}_{2}$ at $37^{\circ} \mathrm{C}$, and the medium changed every 2 days.

The extracts fluid were prepared as previously reported by Gomes et al. ${ }^{25}$ Succinctly, extracts fluids were obtained by introducing the HA scaffolds in a $50 \mathrm{~mL}$ conical tube with flip-top cap (BD Falcon ${ }^{\mathrm{TM}}$, USA) and complete DMEM culture medium was added. For all tests a ratio of outer surface of HA scaffolds to DMEM medium equal to $30 \mathrm{~cm}^{2} \mathrm{~mL}^{-1}$ was used. Then, the tubes were transferred to a thermostatic bath at $37^{\circ} \mathrm{C}$ and $60 \mathrm{rpm}$ for the period of 3 days. Different concentrations of HA scaffolds extracts $(25,50,75$, and $100 \%)$ were prepared. A latex rubber extract was used as positive control.

After reaching confluence, L929 cells were trypsinized ( $0.25 \%$ trypsin/EDTA solution, Sigma Chemical, USA) from a culture flask, and a diluted cell suspension was prepared to achieve a cellular concentration of $8 \times 10^{4}$ cells $\mathrm{mL}^{-1}$. Afterwards, $1.6 \times 10^{4}$ cells were seeded in each well of a 96-well plate (five replicates per sample). Cells were incubated for $48 \mathrm{~h}$ in a $5 \% \mathrm{CO}_{2}$ incubator at $37^{\circ} \mathrm{C}$, until achieving $80-90 \%$ of confluence. Afterwards, the culture medium in each well was replaced with the extraction fluids and incubated for $72 \mathrm{~h}$. Then, an MTS assay was performed using 3-(4, 5-dimethylthiazol-2-yl)-5(3-carboxymethoxyphenyl)-2-(4-sulfophenyl)-2H-tetrazolium) (MTS, Promega, USA), whereas cellular morphology was assessed by optical microscope (Zeiss-Axiovert 40, Germany). The cell viability (\%) was calculated and compared with the tissue culture polystyrene (TCPS). All experiments were performed in triplicate.

\section{Cell viability and adhesion studies}

Rat bone marrow stromal cells (RBMSCs) were obtained from femora of 7 week-old male Fischer 344/N rats (SLC, Japan). The animals were sacrificed following the protocol approved by the Ethics Committee at the Tissue Engineering Research Center (Amagasaki, Japan). Then, the femoras were collected under aseptic conditions, and the soft tissue were eliminated. The epiphyseal regions were removed and the marrow flushed out with freshly prepared complete Eagle's minimum essential medium (MEM, Nacalai Tesque, Japan) with 15\% FBS (JRH Biosciences, USA) and $1 \%$ antibiotic-antimycotic (Nacalai Tesque, Japan) solution, into a $15 \mathrm{~mL}$ Falcon. The RBMSCs were expanded in $\mathrm{T} 75 \mathrm{~cm}^{2}$ (BD Biosciences Discovery Labware, Bedford, USA) culture flasks in the presence of complete culture medium and expanded under standard culturing conditions. The culture medium was changed each 2 or 3 days. After cells reach confluency, $1 \mathrm{~mL}$ of $0.05 \%$ tripsin- $0.53 \mathrm{mM}$ EDTA (Invitrogen, USA) solution was added to detach the cells from the substrate. Then, complete culture medium was added and RBMSCs (passage 1, P1) were centrifuged at $900 \mathrm{rpm}$ for $5 \mathrm{~min}$. The cells re-suspended with $10 \mathrm{~mL}$ of complete culture medium, and cells counted using an automated counter (Cell Counter Sysmex F-520, Japan). Viability of RBMSCs was also analyzed with a NucleoCounter (Chemometec, Denmark), prior seeding. ${ }^{26}$ After that, RBMSCs were seeded onto the HA scaffolds at a cellular density of $5 \times 10^{2}$ cells per scaffold, $1 \times 10^{3}$ cells per scaffold, $5 \times 10^{3}$ cells per scaffold and $1 \times 10^{4}$ cells per scaffold and cultured in MEM medium for 24 h, 3 and 7 days under static conditions. After each time period, the ATP content which signals the presence of metabolically active cells was measured by means of performing a CellTiter-Glo ${ }^{\mathbb{R}}$ luminescent cell viability assay (Promega Corporation, USA). The luminescence was measured using opaque-walled multi-well plate in a microplate reader (Wallac ARVOsx 1420, Perkin-Elmer Life and Analytical Sciences, USA). This assay is based on a luminescence signal that is proportional to the amount of ATP, which by its turn is directly proportional to the number of viable cells.

Moreover, cell adhesion and proliferation were investigated using a LIVE/DEAD viability assay kit (Molecular Probes). RBMSCs were incubated with two probes, calceinAM (green color) and ethidium homodimer-1 (EtdD-1, bright red color), for intracellular esterase activity and plasma membrane integrity, respectively. ${ }^{27}$ Then, specimens were observed under a 3D fluorescence microscope 


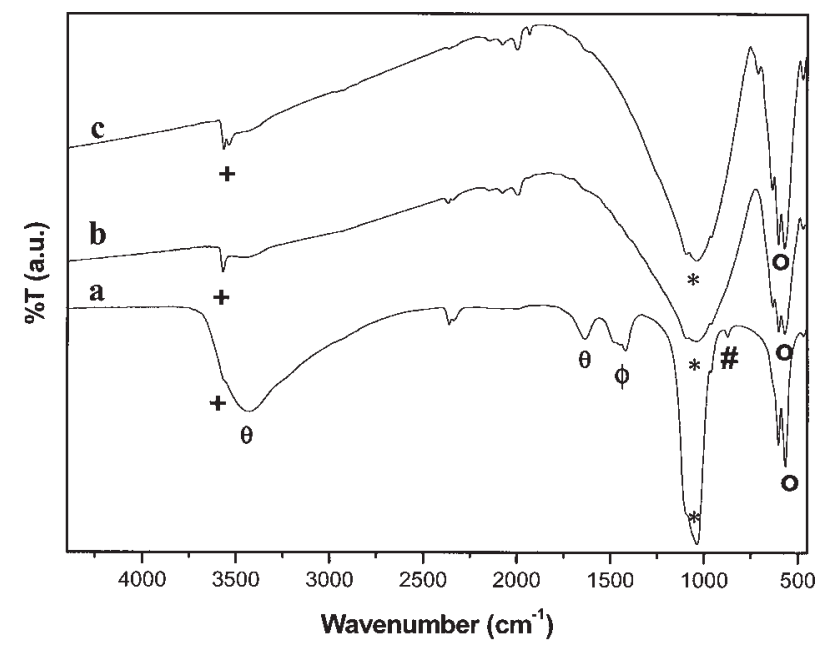

Figure 3. FTIR spectra of (a) HA synthesized by a precipitation method, (b) HA sintered at $1300^{\circ} \mathrm{C}$, and (c) HA scaffolds sintered at $1300^{\circ} \mathrm{C}$.

(Olympus SZX12 stereomicroscope, OLYMPUS, Japan) and SEM. All experiments were carried out three times using a minimum of three samples per experimental condition.

\section{RESULTS AND DISCUSSION}

There is a huge clinical demand for novel synthetic tissue engineered scaffolds. Porosity, pore size and interconnectivity of the biomaterial scaffolds are known to play a critical role in bone formation. ${ }^{28}$ Therefore, among the key requirements that should be idealized, scaffolds architecture is one of the most important features. However, the balanced porosity/ mechanical performance of the scaffolds is an issue that must not be forgotten, and thus should also be explored. To address this issue the present work describes a methodology for the preparation of HA scaffolds to find applications on bone tissue engineering. These scaffolds were successfully obtained by impregnating a PU sponge with HA particles, followed by burning the sacrifice polymeric template and sintering the final HA porous structure (Fig. 1). It is noteworthy that centrifugation (step 2) is a crucial for optimizing the 3D architecture of the scaffolds. It removes the excessive impregnation of HA slurry and this method allows obtaining a uniform porosity across the scaffold and macro- and openpore structure.

The macroscopic appearance of the typical HA scaffold is shown in Figure 2. It can be observed that the HA scaffolds retained the typical shape of the original PU sponge and possess a trabeculae-like architecture.

FTIR analysis was performed to assess the chemical changes on the HA structures during processing.
Figure 3 shows the FTIR spectra of HA before and after sintering. The results confirmed previous ones $^{29}$ that demonstrated, in both cases the existence of characteristic bands of HA, namely at 598 and $559 \mathrm{~cm}^{-1}(\bigcirc)$, and at $1020 \mathrm{~cm}^{-1}\left(^{*}\right)$ attributed to $\mathrm{PO}_{4}^{3-}(\vee 4)$ and $\mathrm{PO}_{4}^{3-}(\vee 3)$ groups, respectively [Fig. 3(a-c)]. Another typical HA band that can be observed is assigned to the stretching mode of $\mathrm{OH}$ group at $3572 \mathrm{~cm}^{-1}(+)$. Moreover, it is also possible to observe the loosening of $\mathrm{OH}$ groups $(\theta)$ from adsorbed, and bending mode of $\mathrm{H}_{2} \mathrm{O}$ after sintering HA. Comparing the sintered HA [Fig. 3(b)] and HA scaffolds [Fig. 3(c)] it is possible to confirm that no differences were observed, and no characteristic peaks of organic groups were found. This result clearly indicates that the heat treatment cycle applied is critical to avoid the undesired traces of PU sponge. To further clarify this issue thermogravimetric analyses (TGA) were performed. Figure 4 shows the TGA of the PU sponges, PU sponges impregnated with HA before burning and sintered HA scaffolds. From results it can be seen that the ratio between HA:PU sponge was 80:20 wt \% [Fig. 4(b)]. Moreover, it can be seen that the melting point of PU sponges is about $300^{\circ} \mathrm{C}$, and PU sponge is completely burned around $400^{\circ} \mathrm{C}$. These findings have demonstrated that the thermal treatment of the $\mathrm{HA} / \mathrm{PU}$ sponges at $900^{\circ} \mathrm{C}$ for the period of $24 \mathrm{~h}$ followed by sintering at $1300^{\circ} \mathrm{C}$ proved to be adequate for the completely eliminating the PU sponges. This is particularly evident in Figure 4(c), because no mass changes on the sintered HA scaffolds were detected.

It has been reported that sintering temperatures and sintering time have great effect on sintered density of different apatites. ${ }^{30,31}$ Therefore, by increasing the sintered density we expected to increase the final

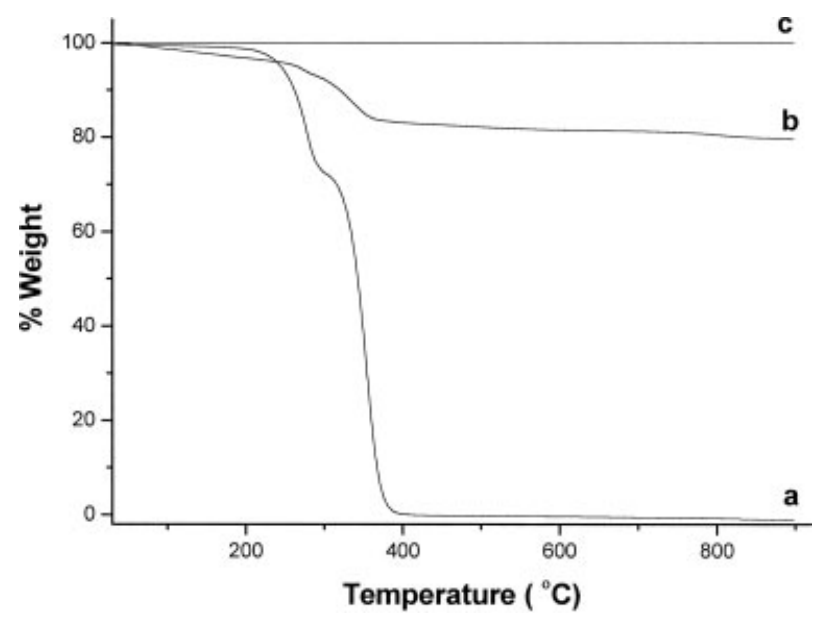

Figure 4. TGA analysis of (a) PU sponges, (b) PU sponge impregnated with HA before burning, and (c) HA scaffolds sintered at $1300^{\circ} \mathrm{C}$. 


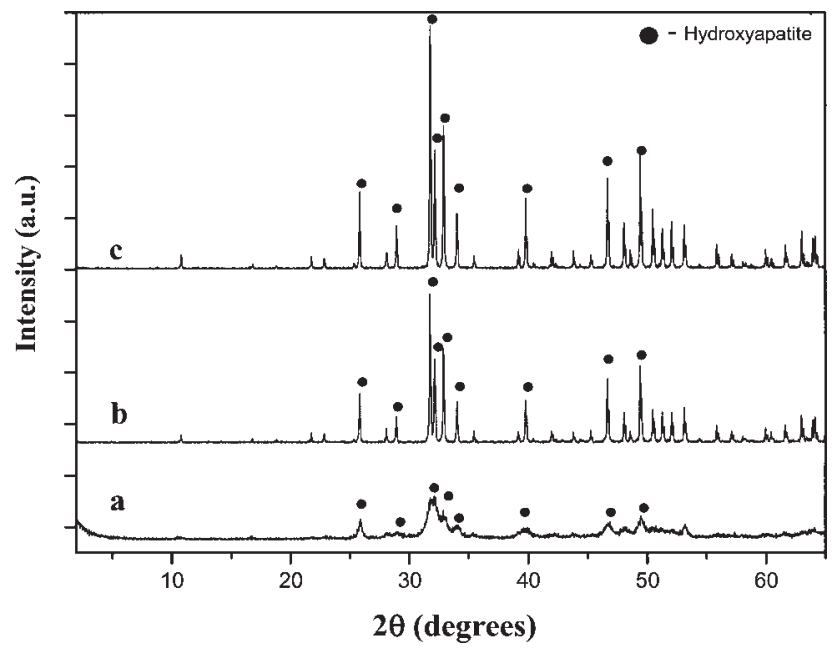

Figure 5. XRD patterns of (a) HA synthesized by a precipitation method, (b) HA sintered at $1300^{\circ} \mathrm{C}$, and (c) HA scaffolds sintered at $1300^{\circ} \mathrm{C}$.

mechanical properties of the HA scaffolds. However, it is also known that high temperatures may affect the crystallinity and phase content of HA. ${ }^{32}$ Figure 5 shows the XRD pattern of HA before and after different heat treatments. Examining the XRD patterns [Figs. $5(\mathrm{a}-\mathrm{c})]$ and comparing with that of the stand- ard file for HA from JCPDS (9-432) it can be observed that the peaks are perfectly matching. The XRD pattern of synthesized HA was found to be amorphous [Fig. 5(a)]. After sintering the crystallinity of HA increased and no decomposition products such as $\alpha$ - or $\beta$-tricalcium phosphates (TCP) ${ }^{32}$ were detected. The complementary FTIR data also revealed the presence of typical $\mathrm{OH}$ groups [Fig. $3(\mathrm{~b}, \mathrm{c})]$ of the $\mathrm{HA}^{33}$ showing that the synthesized HA is quite stable upon sintering of the materials at $1300^{\circ} \mathrm{C}$ for $3 \mathrm{~h}$. As previously reported, the XRD data is also in good attainment with the FTIR spectra [Fig. 3(a)]. FTIR spectrum show that carbonate ions are observed in the as synthetized HA, the bands assigned to carbonate $v 2$ and $v 3$ at $875 \mathrm{~cm}^{-1}$ (\#) and at $1650-1300 \mathrm{~cm}^{-1}$, respectively. The XRD study revealed that the carbonate ions observed by FTIR are assigned to surface ones, rather than being embedded within the lattice of phosphate ions. ${ }^{29}$

To evaluate the microstructure of the HA scaffolds, SEM analysis were performed as shown in Figure 6. The SEM images of the PU foams evidenced an "open-cell" and highly interconnected porous structure [Fig. $6(a, b)]$, that facilitated the impregnation of hydroxyapatite particulates. From Figure 6(c) it can be observed that the architecture of
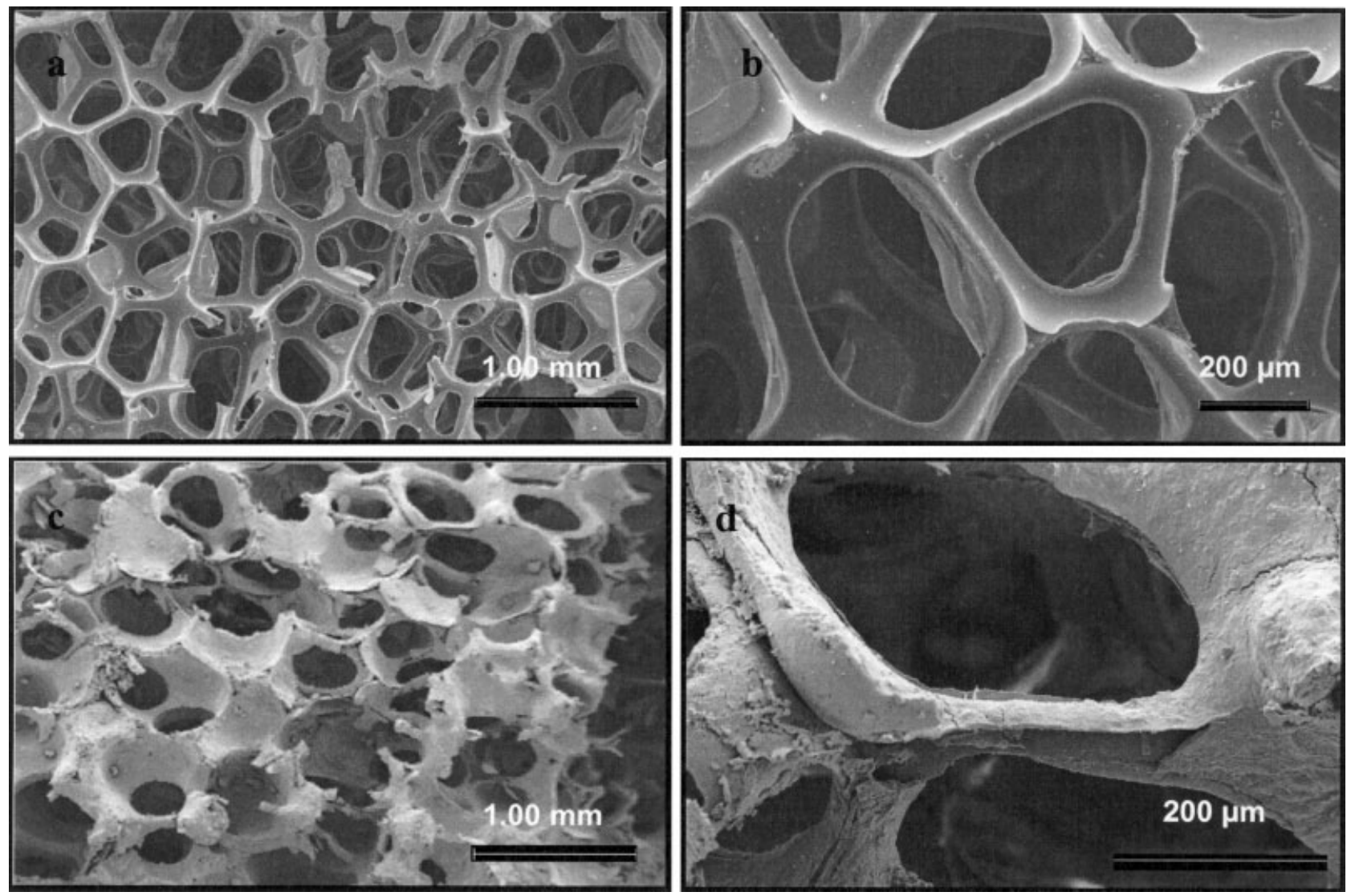

Figure 6. SEM micrographs of (a) PU sponge, (b) typical PU "open-cell" pore, (c) HA scaffold, and (d) typical macropore of the HA scaffolds. 
the obtained HA scaffolds is analogous to the sacrifice template. In addition, the pore geometry is also quite similar [Fig. 6(b,d)], showing a macroporous and highly interconnected structure with pore size comprised in the range of 50-600 $\mu \mathrm{m}$. Such type of morphology and pore dimension has been shown to be adequate for bone tissue engineering purposes. ${ }^{28,34,35}$ Note that the final pore architecture could be easily controlled by changing the structure of the PU foam. These results have demonstrated that the centrifugation step is required to prevent the formation of an external "skin-like" layer, that is non-porous HA layer which can be a disadvantage for the cells adhesion and in-growths during seeding as well as proliferation and proper flow of culture medium. ${ }^{35,36}$

The structure and architecture of the HA scaffolds was further examined in a nondestructive manner by means of $\mu-C T$ analysis (Fig. 7). Figure 7(a) shows the 2D morphometric analysis of the HA scaffolds. It revealed that the mean porosity is about (67.8 \pm $5.0 \%$. Additionally, it can be seen that scaffolds present a uniform architecture and pore distribution. No gaps or empty spaces were observed, that is the impregnation technique allows obtaining 3D structures mimicking the PU template. As previously mentioned, besides the need of scaffolds high porosity, the pores should be interconnected to allow the diffusion of culture medium, metabolic wastes and oxygen, and to facilitate the infiltration and proliferation of cells. ${ }^{37}$ The transversal [Fig. 7(b)] and longitudinal [Fig. 7(c)] views of the HA scaffolds, clearly showed that pore network is highly interconnected (black arrows). This result demonstrates that the centrifugation step not only prohibits the formation of an external "skin-like" layer but also allows a uniform pore distribution and interconnectivity across the HA scaffolds.

It is well known that a compromise between porosity and mechanical properties exists, where higher porosity results in lower mechanical strength of the scaffold. ${ }^{38,39}$ The compressive strength of the HA scaffolds was found to be $30.2 \pm 6.0 \mathrm{MPa}$. Previous reports have shown that for a HA scaffolds possessing $77 \%$ of porosity compressive strength was about 17.4 MPa. ${ }^{40}$ Therefore, as compared with others ceramic porous structures described in literature, ${ }^{23,40}$ our data present a good compromise between porosity and mechanical performance, that is $(67.8 \pm 5.0) \%$ and $30.2 \pm 6.0 \mathrm{MPa}$, respectively.

In the present work another issue that was address consisted on evaluating in vitro, the bioactivity behavior of the HA scaffolds. Figure 8 shows the SEM images of the surface of HA scaffolds before and after immersion in SBF for 1-15 days. It was possible to observe the deposition of precipitates after 1 day [Fig. 8(b)], which tend to be more
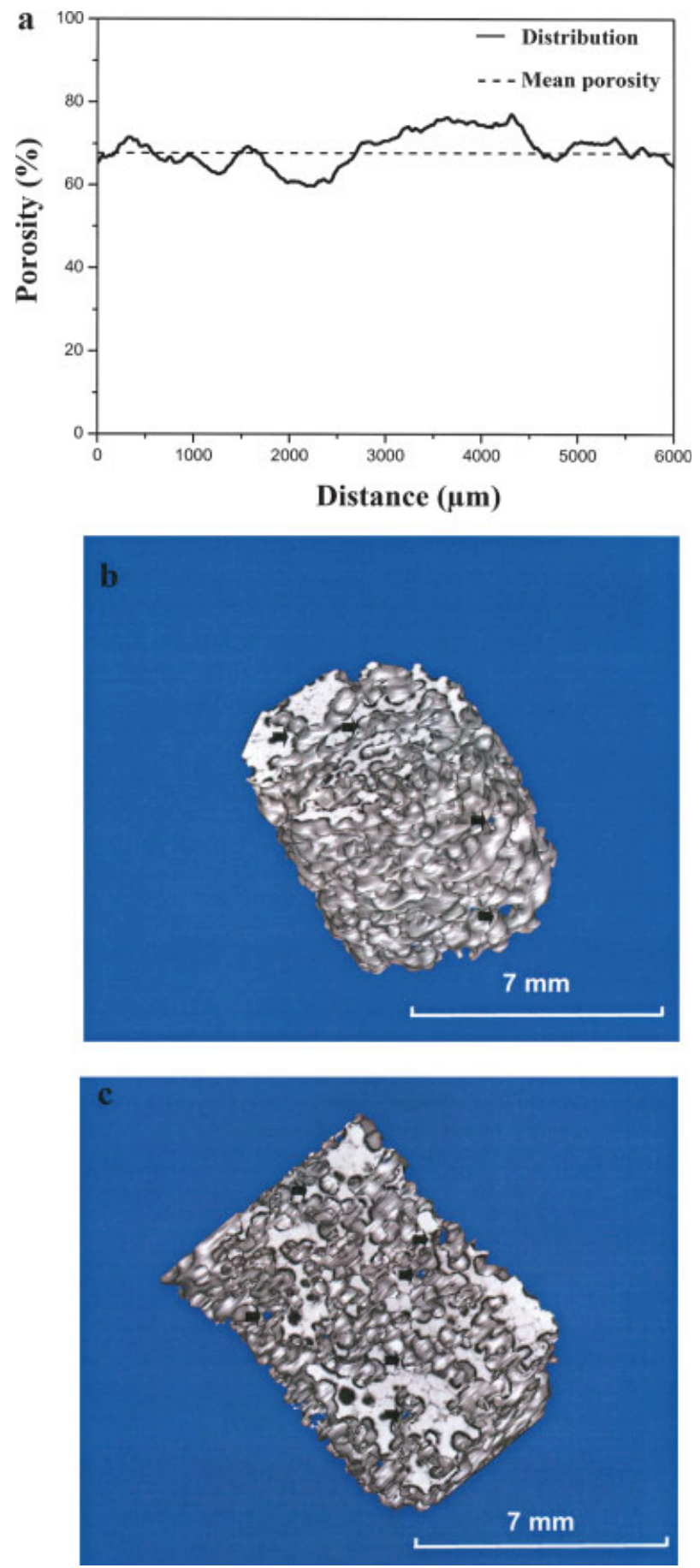

Figure 7. $\mu-\mathrm{CT}$ analysis of HA scaffolds (a) 2D histomorphometric analysis, (b) transversal view, and (c) longitudinal view (see complementary data). [Color figure can be viewed in the online issue, which is available at www. interscience.wiley.com.]

pronounced for longer soaking time [Fig. 8(c,d)]. The formation of these precipitates, which were covering the whole HA surface, resembles the "cauliflowerlike" morphology of apatite formed in vitro onto bioactive surfaces. Additionally, changes in calcium (Ca) and phosphorus (P) ions in SBF solution was 

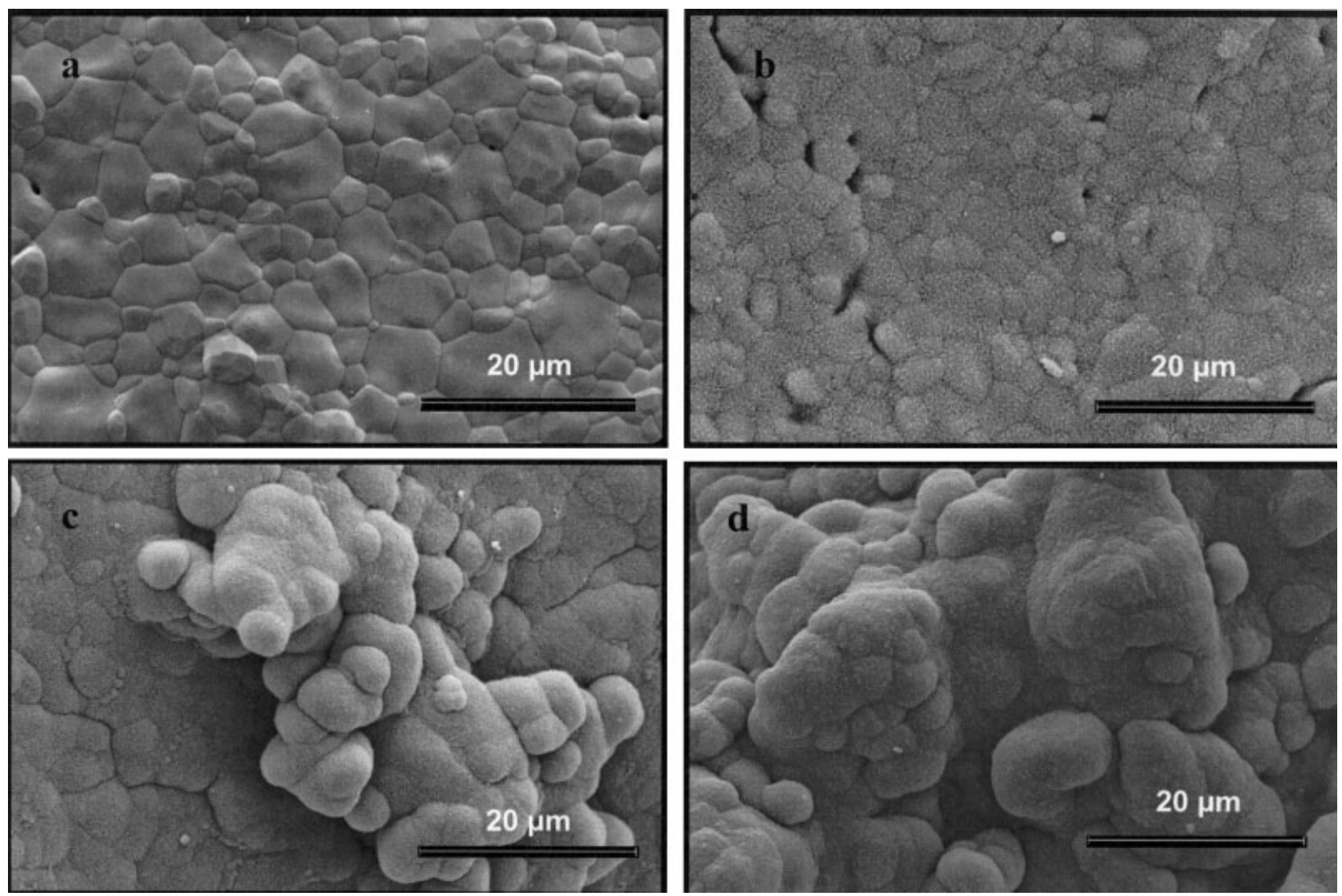

Figure 8. SEM micrographs of the surface of the macroporous HA scaffolds after immersion in SBF for (a) 0 day, (b) 1 days, (c) 7 days, and (d) 15 days.

also monitored by ICP. Figure 9 shows that Ca concentration increased in the SBF solution in the first $24 \mathrm{~h}$. However, it is not detected an expected increase in $\mathrm{P}$ concentration during this period. This can be explained due to a fast consumption of $\mathrm{P}$ during apatite nucleation phase. From day 1 to day

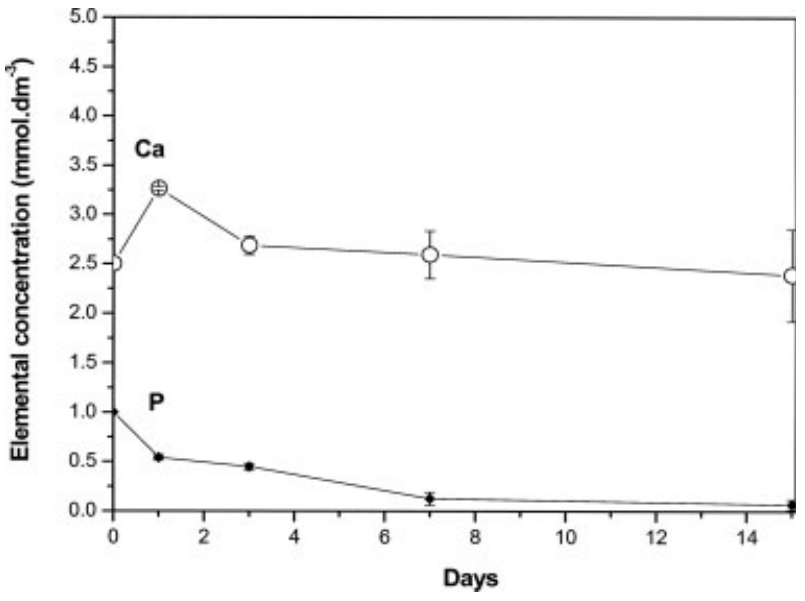

Figure 9. Profile of $\mathrm{Ca}$ and $\mathrm{P}$ ions in the SBF solution after soaking the macroporous HA scaffolds from day 0 up to day 15.
15, we assist to both decrease in the concentration of $\mathrm{Ca}$ and $\mathrm{P}$. This trend may be a consequence of the consumption of both calcium and phosphorus upon the deposition of the apatite layer at the surface of the HA scaffolds, as detected by SEM [Fig. 8(b-d)] images. These findings are in agreement with the data available in literature, ${ }^{41}$ which has been shown that HA are bioactive in nature due to a phenomenon involving the dissolution of calcium and phosphate ions from the HA.

As previously reported by Kirkpatrick et al., there are several ways to assess the toxicity in vitro. ${ }^{42}$ In this study, L929 cells were used for preliminarily screen toxicity. Cytotoxicity of the HA scaffolds was initially assessed through cell death observation in the inverted microscope (Fig. 10). It can be observed that after $72 \mathrm{~h}$ in contact with a latex rubber extract (positive control), the L929 cells round up and detached from the culture substratum, which is indicative of the high cytotoxicity of the material [Fig. 10(b)]. On the contrary, when exposing to the different concentrations of HA extract [Figs. 9 and 10(cf)], the L929 cells exhibited a normal morphology, proliferated well and established a monolayer when comparing with the negative control [Fig. 10(a)]. Therefore, these preliminary results show that no 

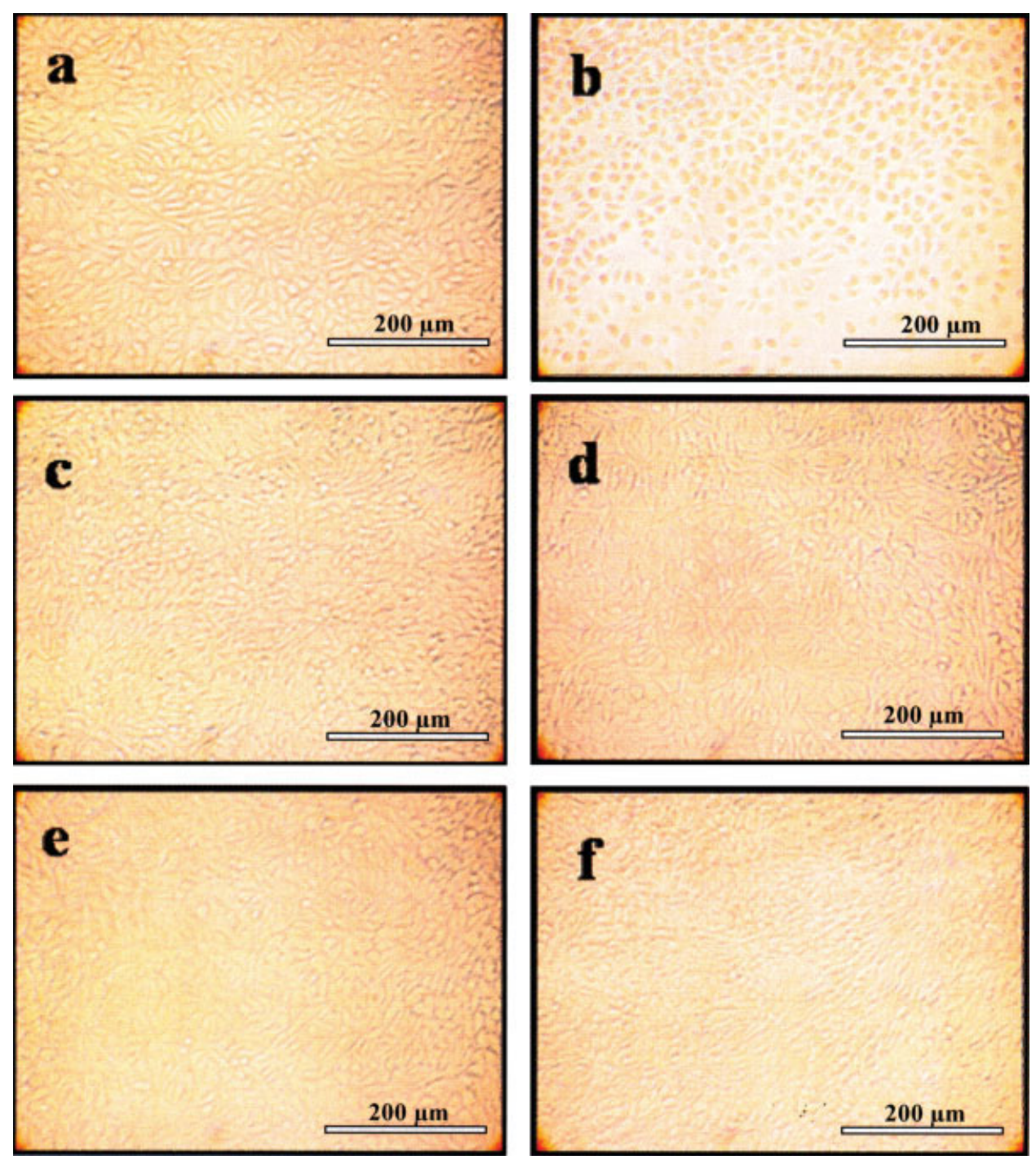

Figure 10. L929 cells after contacting $72 \mathrm{~h}$ with the extract fluids (a) complete culture medium (negative control), (b) latex rubber leachables (positive control), (c) 25\% HA leachables, (d) 50\% HA leachables, (e) 75\% HA leachables, and (f) 100\% HA leachables. [Color figure can be viewed in the online issue, which is available at www.interscience.wiley.com.]

toxic traces of PU sponges remained on the HA scaffolds, and that HA scaffolds were biocompatible. Complementarily, cell viability was investigated by carrying out the MTS test (Fig. 11). The results once corroborated the direct observation under the microscope which showed that L929 cells were viable after contacting with the different HA extract fluids for the period of $72 \mathrm{~h}$.

Cell viability and proliferation on the scaffolds is one of the prerequisite for the 3D supports find applications in the TE. ${ }^{43}$ To investigate other aspects of cytotoxicity, such as the cell/scaffold interactions, direct contact experiments were performed on the macroporous HA scaffolds using rat bone marrow stromal cells (RBMSCs). On the other hand, for optimizing the cell seeding efficiency in respect to cell adhesion and proliferative capacity of RBMSCs onto

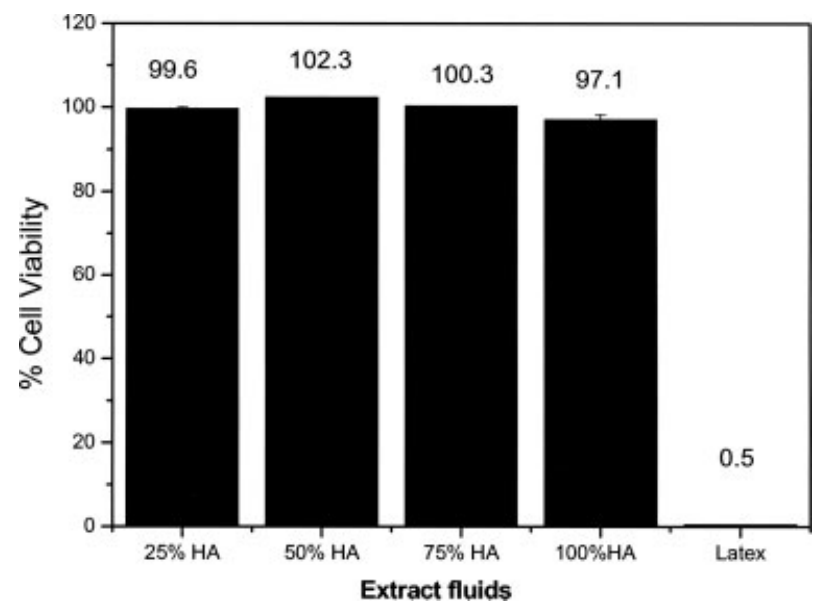

Figure 11. Percentage of L929 cell viability versus extract fluids. 


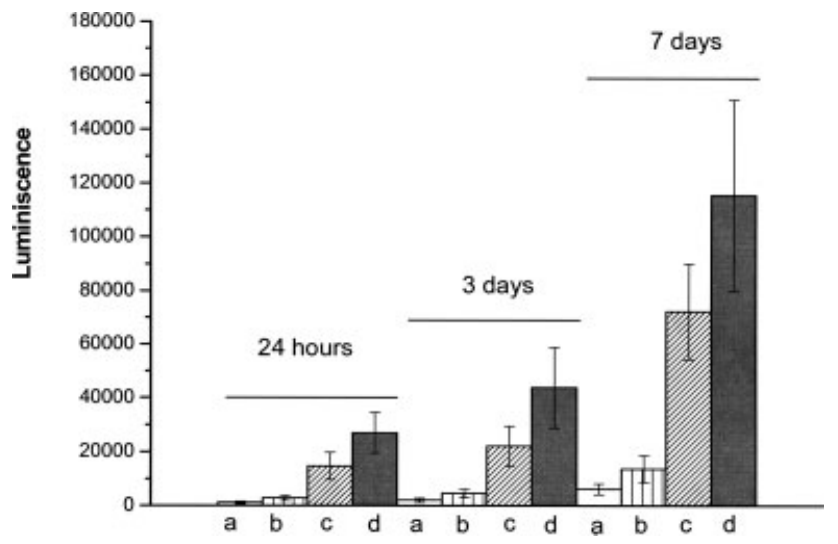

Figure 12. Cell viability assay of RBMSCs seeded at different cell densities onto the surface of the macroporous HA scaffolds after $24 \mathrm{~h}, 3$ and 7 days: (a) $5 \times 10^{2}$ cells per scaffold (b) $1 \times 10^{3}$ cells per scaffold, (c) $5 \times 10^{3}$ cells per scaffold, and (d) $1 \times 10^{4}$ cells per scaffold. Cell numbers correlates with luminiscence.

the macroporous HA scaffolds different cell numbers were tested. Figure 12 shows the luminescent cell viability assay of RBMSCs seeded onto the surface of the HA scaffolds after culturing for 7 days. This assay is based on a luminescence signal that is proportional to the amount of ATP, which signals the presence of metabolically active cells. From Figure 12 it can be observed that RBMSCs seeded at higher cell numbers proliferated well and were viable after culturing onto the macroporous HA scaffolds for 7 days. On the contrary, the low cell density has shown to influence negatively the proliferation of RBMSCs, as observed by the low cell numbers, after 7 days of culturing. Nevertheless, the number of viable cells increased with an increase of culture time for all cell densities tested. This data shows that cell seeding efficiency increased with the increase in cell concentration. This is an expected result because it has been shown that cells needs a proper microenvironment not only with respect to $3 \mathrm{D}$ scaffold but also by means of interacting with other cells through cell-cell junctions and signaling. ${ }^{44,45}$ Therefore, this data demonstrated that the cell seeding conditions, namely the cell numbers needs to be optimized. The high cell concentration tested seems to be more adequate for the RBMSCs/HA constructs fully achieve physiologic functions upon implantation.

Figure 13 shows the fluorescence microscopy images of the HA scaffolds seeded with RBMSCs after performing a two-color fluorescence LIVE/DEAD cell viability assay. This type of assay allows distinguishing live from dead cells because calcein-AM is enzimatically converted into calcein, which is retained within live cells and produces an intense green fluorescence. On the other hand, dead cells are stained in a bright red fluorescence because EtdD-1 only enters cells with damaged membranes and binds to nucleic acids. From the fluorescence signals it can be observed that RBMSCs adhered, proliferated and remained viable after 7 days. Moreover, dead cells were present in low numbers as detected by the low bright red fluorescence. Moreover, it can be seen that RBMSCs were able to penetrate deeper into the core of the HA scaffolds [Fig. 13(c)]. This is an important data since it has been shown ${ }^{35,39}$ that cell infiltration and distribution within the whole scaffold will greatly affect the overall performance of the cells/scaffold construct.

To further investigate the RBMSCs adhesion onto the surface of the macroporous HA scaffolds SEM analysis were also carried out. Figure 14 shows the SEM images of the RBMSCs on the surface of the macroporous HA scaffolds after $24 \mathrm{~h}$ and 7 days. It can be observed that RBMSCs aggregated and adhered onto the surface of the HA scaffolds but presents a spherical morphology, after $24 \mathrm{~h}$ [Fig. 14(a)]. The morphology and small size are typical of the cells initial anchorage stage. After a longer period of culturing, RBMSCs spread actively and presented a flatten morphology showing a good anchoring to the substrate by multiple lamellipodia [Fig. 14(b)].

Despite the biocompatibility and capacity of supporting normal cellular functions, the macroporous
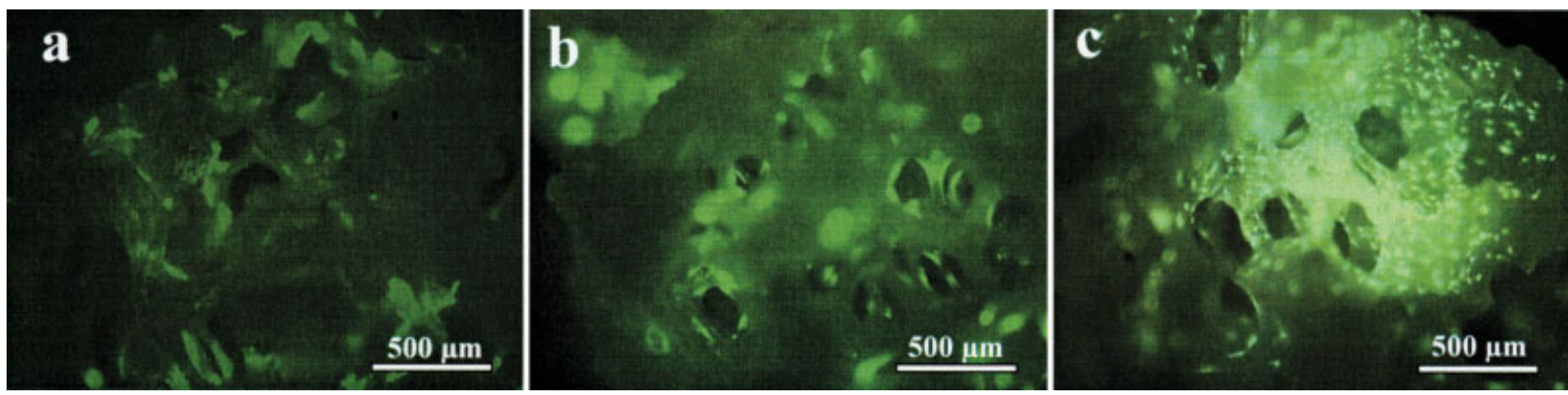

Figure 13. Fluorescence microscopy images of the macroporous HA scaffolds seeded with RBMSCs at a cell density of $1 \times 10^{4}$ cells per scaffold after culturing for: (a) $24 \mathrm{~h}$, (b) 3 days, and (c) 7 days. [Color figure can be viewed in the online issue, which is available at www.interscience.wiley.com.] 

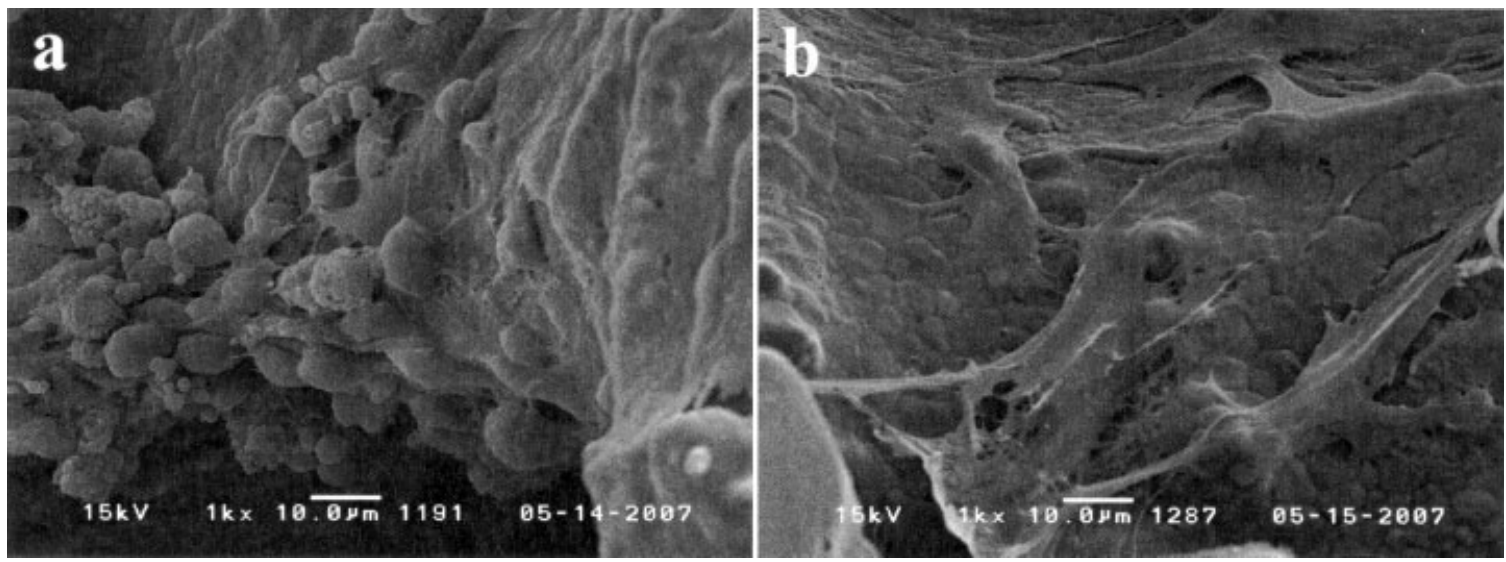

Figure 14. SEM images of the macroporous HA scaffolds seeded with RBMSCs at a cell density of $1 \times 10^{4}$ cells per scaffold after culturing for: (a) $24 \mathrm{~h}$ and (b) 7 days.

HA scaffolds also have to support the differentiation of the stem cells both in vitro and in vivo. It can be seen from Figure 14 that there are no indications of osteogenic differentiation, namely the extracellular mineralized matrix cannot be detected. This is an expected result because osteogenic factors medium were not added to culture medium. In contrast hydroxyapatite is known to lack the osteoinductive capacity. This is a relevant feature that needs to be met in a variety of bone related clinical strategies and to which our research groups ${ }^{46,47}$ have been giving great deal of attention. Moreover, the present data is promising because in future experiments we propose to evaluate the HA/RBMSCs constructs functionality, namely the ability of the HA scaffolds to support the RBMSCs osteogenesis and bone formation, in vitro and in vivo, respectively.

\section{CONCLUSIONS}

This work demonstrated that it is possible to prepare sintered hydroxyapatite scaffolds with high interconnectivity by impregnating an "open-cell" PU sponge into a HA slurry, followed by burning the "sacrifice template". The preparation route was optimized for producing macroporous HA structures with controlled morphology, easily mediated by the architecture of the PU sponge. In vitro tests have demonstrated that such constructs are bioactive, as observed by the formation of an apatite layer after 1 day of immersion in SBF solution. The biocompatible behavior of the macroporous HA scaffold was demonstrated as evidenced by the noncytotoxic effect over L929 cells. Moreover, the cell/material interaction tests have shown that the rat bone marrow stromal cells adhered, proliferated well and remained viable on the macroporous hydroxyapatite scaffolds. More importantly, the cells were able to populate the inner of the macroporous hydroxyapatite scaffolds. Therefore, the physicochemical and biological properties of the macroporous hydroxyapatite scaffolds have shown to suitable for find applications in bone tissue-engineering scaffolding.

The authors wish to acknowledge Materialise (Belgium) for the MIMICS ${ }^{\mathbb{R}}$ software provided to us and LBI (Vienna, Austria) for the $\mu$-CT scans. We also would like to thank Canon Foundation in Europe.

\section{References}

1. Abukawa H, Shin M, Williams WB, Vacanti JP, Kaban LB, Troulis MJ. Reconstruction of mandibular defects with autologous tissue-engineered bone. J Oral Maxillofac Surg 2004;62:601-606.

2. Petite H, Viateau V, Bensaid W, Meunier A, Pollak C, Bourguignon M, Oudina K, Sedel L, Guillemin G. Tissue-engineered bone regeneration. Nat Biotechnol 2000;18:959-963.

3. Saint-Cyr M, Miranda D, Gonzalez R, Gupta A. Immediate corticocancellous bone autografting in segmental bone defects of the hand. J Hand Surg 2006;31:168-177.

4. Merkx MAW, Maltha JC, Freihofer HPM, Kuijpers-Jagtman AM. Incorporation of three types of bone block implants in the facial skeleton. Biomaterials 1999;20:639-645.

5. Su-Gwan K, Hak-Kyun K, Sung-Chul L. Combined implantation of particulate dentine, plaster of Paris, and a bone xenograft (Bio-Oss(R)) for bone regeneration in rats. J Craniomaxillofac Surg 2001;29:282-288.

6. Babensee JE, Anderson JM, McIntire LV, Mikos AG. Host response to tissue engineered devices. Adv Drug Delivery Rev 1998;33:111-139.

7. Kahan BD. Immunosupressive therapy. Curr Opin Immunol 1992;4:553-560.

8. Meinel L, Fajardo R, Hofmann S, Langer R, Chen J, Snyder B, Vunjak-Novakovic G, Kaplan D. Silk implants for the healing of critical size bone defects. Bone 2005;37:688-698.

9. Ahmad CS, Guiney WB, Drinkwater CJ. Evaluation of donor site intrinsic healing response in autologous osteochondral grafting of the knee. Arthroscopy 2002;18:95-98.

10. Langer R, Vacanti JP. Tissue Engineering. Science 1993;260: 920-926.

11. Ozawa S, Kasugai S. Evaluation of implant materials (hydroxyapatite, glass-ceramics, titanium) in rat bone marrow stromal cell culture. Biomaterials 1996;17:23-29. 
12. Li Z, Ramay HR, Hauch KD, Xiao D, Zhang M. Chitosanalginate hybrid scaffolds for bone tissue engineering. Biomaterials 2005;26:3919-3928.

13. Chu TMG, Orton DG, Hollister SJ, Feinberg SE, Halloran JW. Mechanical and in vivo performance of hydroxyapatite implants with controlled architectures. Biomaterials 2002;23: 1283-1293.

14. Sepulveda P, Bressiani AH, Bressiani JC, Meseguer L, Konig BK Jr. In vivo evaluation of hydroxyapatite foams. J Biomed Mater Res. 2002;62:587-592.

15. Porter AE, Patel N, Skepper JN, Best SM, Bonfield W. Comparison of in vivo dissolution processes in hydroxyapatite and silicon-substituted hydroxyapatite bioceramics. Biomaterials 2003;24:4609-4620.

16. Hasegawa $\mathrm{S}$, Ishii $\mathrm{S}$, Tamura J, Furukawa T, Neo M, Matsusue $Y$, Shikinami Y, Okuno M, Nakamura T. A 5-7 year in vivo study of high-stength hydroxyapatite/poly(L-lactide) composite rods for the internal fixation of bone fractures. Biomaterials 2006;27:1327-1332.

17. Driessens FCM, Ramselaar MMA, Schaken HG, Stols ALH, van Mullem PJ, Wijn JR. Chemical reactions of calcium phosphate implants after implantation in vivo. J Mater Sci Mater Med 1992;3:413-417.

18. Schnettjer R, Alt V, Dingeldein E, Pfefferle H-J, Kilian O, Meyer C, Heiss C, Wenisch S. Bone ingrowth in bFGF-coated hydroxyapatite ceramic implants. Biomaterials 2003;24:46034608.

19. Dee KC, Rueger DC, Andersen TT, Bizios R. Conditions which promote mineralization at the bone-implant interface: A model in vitro study. Biomaterials 1996;17:209-215.

20. Srouji S, Livne E. Bone marrow stem cells and biological scaffold for bone repair in aging and disease. Mech Ageing Dev. 2005;126:281-287.

21. Ohgushi H, Kotobuki N, Funaoka H, Machida H, Hirose M, Tanaka Y, Takakura Y. Tissue engineered ceramic artificial joint-ex vivo osteogenic differentiation of patient mesenchymal cells on total ankle joints for treatment of osteoarthritis. Biomaterials 2005;26:4654-4661.

22. Abukawa H, Terai H, Hannouche D, Vacanti JP, Kaban LB, Troulis MJ. Formation of a mandibular condyle in vitro by tissue engineering. J Oral Maxillofac Surg 2003;61:94-100.

23. Uemura T, Dong J, Wang Y, Kojima H, Saito T, Iejima D, Kikuchi M, Tanaka J, Tateishi T. Transplantation of cultured bone cells using combinations of scaffolds and culture techniques. Biomaterials 2003;24:2277-2286.

24. Kokubo T, Kushitani H, Sakka S, Kitsugi T, Yamamuro T. Solutions able to reproduce in vivo surface-structure changes in bioactive glass-ceramic A-W. J Biomed Mater Res 1990;24: 721-734.

25. Gomes ME, Reis RL, Cunha AM, Blitterswijk CA, Bruijn JD. Cytocompatibility and response of osteoblastic-like cells to starch-based polymers: Effect of several additives and processing conditions. Biomaterials 2001;22:1911-1917.

26. Muraki K, Hirose M, Kotobuki N, Kato Y, Machida H, Takakura Y, Ohgushi H. Assessment of viability and osteogenic ability of human mesenchymal stem cells after being stored in suspension for clinical transplantation. Tissue Eng 2006;12: 1711-1719.

27. Hirose M, Kotobuki N, Machida H, Kitamura S, Ohgushi H, Tateishi T. Osteogenic potential of cryopreserved human bone marrow-derived mesenchymal cells after thawing in culture. Mater Sci Eng C 2004;24:335-359.

28. Karageorgiou V, Kaplan D. Porosity of $3 \mathrm{D}$ biomaterial scaffolds and osteogenesis. Biomaterials 2005;26:5474-5491.

29. Oliveira JM, Silva SS, João F. Mano, Reis RL. Innovative technique for the preparation of porous bilayer hydroxyapatite/ chitosan scaffolds for osteochondral applications. Key Eng Mater 2006;309-311:927-930.

30. Rao WR, Boehm RF. A study of sintered apatites. J Dental Res 1974;53:1351-1354.

31. Kim SR, Lee JH, Kim YT, Riu DH, Jung SJ, Lee YJ, Chung SC, Kim YH. Synthesis of $\mathrm{Si}, \mathrm{Mg}$ substituted hydroxyapatites and their sintering behaviours. Biomaterials 2003;24:13891398.

32. Tampieri A, Cellotti G, Szontagh F, Landi E. Sintering and characterization of HA and TCP bioceramics with control of their strength and phase purity. J Mater Sci Mater Med 1997;8:29-37.

33. Weng J, Liu X-G, Li X-D, Zhang X-D. Intrinsic factors of apatite influencing its amorphization during plasma-spray coating. Biomaterials 1995;16:39-44.

34. Hutmacher DW, Sittinger M, Risbud MV. Scaffold-based tissue engineering: Rationale for computer-aided design and solid freeform fabrication systems. Trends Biotechnol 2004;22:354-362.

35. $\mathrm{O}^{\prime}$ Brien FJ, Harley BA, Yannas IV, Gibson LJ. The effect of pore size on cell adhesion in collagen-GAG scaffolds. Biomaterials $2005 ; 26: 433-441$.

36. Ang TH, Sultana FSA, Hutmacher DW, Wong YS, Fuh JYH, Mo XM, Loh HT, Burdet E, Teoh SH. Fabrication of 3D chitosan-hydroxyapatite scaffolds using a robotic dispensing system. Mater Sci Eng C 2002;20:35-42.

37. Ho ST, Hutmacher DW. A comparison of micro CT with other techniques used in the characterization of scaffolds. Biomaterials 2006;27:1362-1376.

38. Hollister SJ, Maddox RD, Taboas JM. Optimal design and fabrication of scaffolds to mimic tissue properties and satisfy biological constraints. Biomaterials 2002;23:4095-4103.

39. Karageorgiou V, Kaplan D. Porosity of 3D biomaterial scaffolds and osteogenesis. Biomaterials 2005;26:5474-5491.

40. Dong J, Kojima H, Uemura T, Kikuchi M, Tateishi T, Tanaka J. In vivo evaluation of a novel porous hydroxyapatite to sustain osteogenesis of transplanted bone marrow-derived osteoblastic cells. J Biomed Mater Res 2001;57:208-216.

41. Weng J, Liu Q, Wolke JGC, Zhang X, De Groot K. Formation and characteristics of the apatite layer on plasma-sprayed hydroxyapatite coatings in simulated body fluid. Biomaterials 1997;18:1027.

42. Kirkpatrick CJ, Mittermayer C. Theoretical and practical aspects of testing potential biomaterials in vitro. J Mater Sci:Mater Med 1990;1:9-13.

43. Mauney JR, Jaquiery C, Volloch V, Heberer M, Martin I, Kaplan DL. In vitro and in vivo evaluation of differentially demineralized cancellous bone scaffolds combined with human bone marrow stromal cells for tissue engineering. Biomaterials 2005;26:3173-3185.

44. Chen G, Liu D, Maruyama N, Ohgushi H, Tanaka J, Tateishi T. Cell adhesion of bone marrow cells, chondrocytes, ligament cells and synovial cells on a PLGA-collagen hybrid mesh. Mater Sci Eng C 2004;24:867-873.

45. Sun S, Titushkin I, Cho M. Regulation of mesenhymal stem cell adhesion and orientation in 3D collagen scaffold by electrical stimulus. Bioelectrochemistry 2006;69:133-141.

46. Oliveira JM, Rodrigues MT, Silva SS, Malafaya PB, Gomes ME, Viegas CA, Dias IR, Azevedo JT, Mano JF, Reis RL. Novel hydroxyapatite/chitosan bilayered scaffolds for osteochondral tissue-engineering applications: Scaffold design and its performance when seeded with goat bone marrow stromal cells. Biomaterials 2006;27:6123-6137.

47. Kotobuki N, Ioku K, Kawagoe D, Fujimori H, Goto S, Ohgushi H. Observation of osteogenic differentiation cascade of living mesenchymal stem cells on transparent hydroxyapatite ceramics. Biomaterials 2005;26:779-785. 